\title{
New Tumor Event Header
}

National Cancer Institute

\section{Source}

National Cancer Institute. New Tumor Event Header. NCI Thesaurus. Code C156851.

A section header about new tumor activity. 